\title{
La cultura une a los pueblos y evita las guerras
}

Mtro. Ricardo Ancira González*

ntes que nada deseo agradecer la gentil invitación que me hizo el doctor Guillermo Pulido González, Director General de este Centro de Enseñanza para Extranjeros. Es para mí un honor fungir como moderador en esta mesa redonda $A$ ochenta años de la Escuela de Verano, en el marco de los festejos del octogésimo aniversario de nuestro querido Centro.

Festejos que, como han mencionado en sus intervenciones la doctora Olga Elizabeth Hansberg, Coordinadora de Humanidades, y el propio doctor Pulido, se han visto ensombrecidos por los terribles acontecimientos sucedidos hace unos cuantos días en las ciudades de Nueva York y Washington [el atentado terrorista a las torres gemelas del World Trade Center y al Pentágono, la central militar estadunidense, el 11 de septiembre de 2001]. En efecto, nada hay más alejado del espíritu de entendimiento entre los pueblos, espíritu con el que nació la Escuela de Verano, que los recientes atentados que han llenado de luto a los Estados Unidos y al mundo entero.

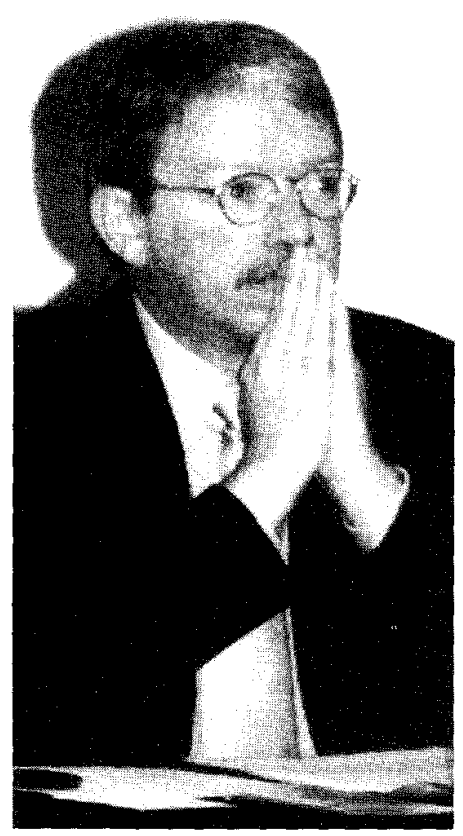

Ricardo Ancira

Durante sus primeros ochenta años de vida, esta escuela, este Centro de Enseñanza, ha acogido a miles de jóvenes provenientes de todos los confines de la tierra. Y aquí han aprendido juntos, han convivido juntos, se han hecho amigos, independientemente de sus nacionalidades, de su credos, de sus orígenes étnicos, de sus lenguas maternas. Esos miles de jóvenes extranjeros "adquirieron el alma mexicana", como lo desearon José Vasconcelos, Julio Torri, Ezequiel Chávez, creadores, junto a tantos otros intelectuales, de la Escuela de Verano, hoy Centro de Enseñanza para Extranjeros. Esos miles de jóvenes constituyen una prueba irrefutable de que la cultura une a los pueblos y evita las guerras.

Es para mí un honor moderar esta mesa redonda en la que participan tan distinguidos académicos, varios de ellos ex-directores del CEPE, que siguen estando muy cerca del Centro.

Sin más preámbulos, me permito presentar a ustedes a los ponentes de la mesa. Cada uno de ellos tocará el tema de la enseñanza de una disciplina académica de las que se imparten en el Centro. El Dr. José G. Moreno de Alba hablará de la enseñanza del español a estudiantes extranjeros; el doctor Álvaro Matute, por su parte, de la enseñanza de la historia; la maestra Sara Martínez, de la literatura mexicana; y la Dra. Beatriz de la Fuente, de la enseñanza del arte mexicano. (Lamentamos que, debido a los recientes acontecimientos, el Dr. Arturo Madrid haya tenido que cancelar su viaje, y no se encuentre aquí con nosotros). 